\title{
Influence of Iur Cost to Patient Satisfaction through Customer Value patients BPJS Hospital in South Sulawesi Province
}

\author{
Marwah Thaha ${ }^{1}$, Amran Razak $^{2}$, Indar ${ }^{2}$, Fridawat Rivai ${ }^{3}$ \\ ${ }^{1}$ Postgraduated Student Faculty of Public Health, ${ }^{2}$ Lecturer of Health Administration and Policy Department, \\ ${ }^{3}$ Lecturer of Hospital Management Department, Faculty of Public Health Hasanuddin University
}

\begin{abstract}
Hospitals as a means of public health services are required to perform optimal service. This is because patient satisfaction is very dependent on the quality of hospital services. This research aims to determine the influence of Iur cost to the satisfaction of BPJS patients through customer value in the province of South Sulawesi Research conducted at Dr Sumantri, Hospital, Andi Makkasau hospital and Lasinrang hospital. The research method used is an analytical observational observation with a cross-sectional study approach. The population in this study is BPJS patients with Iur cost. The sample amount of 300 people is obtained by accidental sampling method. Data collection is obtained through interviews using questionnaires. Data is processed and analyzed using SPSS and AMOS. The results showed that the IUR cost significantly affected the customer value $(\mathrm{p}=0.001)$, the customer value is significantly affected the patient satisfaction $(\mathrm{p}=$ $0.001)$ and the cost of the patient to significantly affect patients satisfaction $(\mathrm{P}=0.001)$. Conclusion of this research is Iur cost can directly affect patient satisfaction and influence indirectly to patient satisfaction through customer value.
\end{abstract}

Keywords: BPJS, customer value, patient satisfaction

\section{Introduction}

Health is a very important need for people and is a major capital in conducting daily activities. To create a society that has a high degree of health, the implementation of development in the health sector is a priority. ${ }^{1}$ Healthcare business becomes one of the media in supporting the health of people in the world. The establishment of various types of healthcare providers ranging from simple such as clinics or health centres to hospitals that have various health supporting facilities. The presence of various health facilities is expected to assist in providing maximum health services to the community. ${ }^{2}$

Public awareness of the importance of health today is increasing as a fundamental measure of life quality, along with the advancement of communication technology and information, socio-economic, cultural, which encourages the development of the role of the service sector. The Indonesian Government through the Ministry of Health since 1 January 2014 held health insurance for the community through the Social Security
Administering Agency (BPJS) held health insurance. Thus the Government is obliged to provide quality healthcare services. Health care is a human right that must be fulfilled by the Government.

Public interest in the BPJS program is demonstrated by the magnitude of interest of the community as a participant of the BPJS program. Data in September 2014 number of participants BPJS Kesehatan in Indonesia as much as 127.3 million people (65\%) and continues to increase, in November 2017 recorded 183,579,086 participants or approximately (70\%) And in September 2018 , the number of participants reached 201,660,548 people, as well as on 1 February 2019 reached $217,549,455$ people. With a figure of 217 million, this means that the number of participants BPJS Kesehatan has reached $81.8 \%$ of the total population of Indonesia which is about 265 million, as data is quoted from the official website of BPJS. Following data participant BPJS Health South Sulawesi year 2019/2020. BPJS Kesehatan 
Report Data of South Sulawesi in 2019, especially in 4 (four) Regency/city consisting of Barru District, Parepare, Pinrang and Sidenreng Rappang who are under the branch office of Parepare, noted that as many as 863,053 people in JKN, in January to July and there are $15 \%$ patients using IUR fee, for people without JKN as many as 183,587 people using IUR cost as much as $23 \% .^{3}$

Hospitals as a means of public health services are required to perform optimal service. It is as hospital accountability to be able to compete with other hospitals in terms of comprehensive and plenary patient services covering the promotive, preventive, curative and rehabilitative aspects as well as a referral centre for public health. ${ }^{4}$ According to Law No. 44 the year 2009 about the hospital that article 29 clause (1) states that each hospital has the obligation to carry out social functions, among others, by providing inadequate/ poor patient service facilities, no upfront emergency services, free ambulance, disaster victims services and extraordinary events, or social service for humanitarian missions. ${ }^{5}$

Patient satisfaction will be fulfilled when the service provided is in accordance with their expectations. ${ }^{6}$ Hawkins and Lonney in Tjiptono mention that the satisfaction attribute consists of the suitability of expectations, interest revisit, willingness to recommend. ${ }^{7}$ The description elaborates that in essence, service users ' satisfaction is identical to the achievement of hope for the service they receive so that the user wishes service in this

If the expectation is fulfilled, it means that the service has given a remarkable quality and also will cause high satisfaction. Conversely, if the expectation is not achieved, then interpreted the quality of service does not fulfil what he hoped for. ${ }^{8}$ hospitals should be able to improve the quality of service because of good quality, will be able to cause (customer value) or good judgment effect in the patient or satisfied, as the purpose of public service is to satisfy the community

The results of the initial survey conducted by researchers for the satisfaction of services held in the Lasinrang hospital and Andi Makassau hospital and Dr Sumantri hospital. There are some views or assessment of the patient's acceptable service is still lacking a good example is that there is no certainty or details of the standard such as the presence of participants in Class 3 BPJS who want to get 2nd-grade treatment must pay the cost of the difference between Class 2 and Grade 3. BPJS only pays class 3 while the difference between Class 3 to Class 2 is paid by the participants. Meanwhile, service in 2nd grade is not maximal.

\section{Materials and Method}

This study included a quantitative research type of analytical descriptive methods with a cross-sectional approach. The research was held in the Lasinrang hospital, Andi Makkasau hospital and Dr Sumantri hospital. The population in this study is BPJS patients who use (IUR cost) or the difference in the cost of service they received in the year 2019. Samples are obtained using the purposive sampling method and obtained a total of 300 respondents. Data collection is conducted through interviews using questionnaires. Data collected is a characteristic of respondents, BPJS membership classes and treatment classes used, customer value, perception of IUR the cost of patients BPJS and patient satisfaction. Data analysis is done in multivariate using the path analysis with the help of AMOS software.

\section{Results}

Based on the results of the study then obtained the results as that based on the category of patient satisfaction level in the Andi Makkasau Hospital known that the number of respondents is satisfied as much as 13 people $(13 \%)$. The respondent who was satisfied amounted to 48 people (48.0\%) while being very satisfied amounting to 39 people $(39.0 \%)$. In the Lasinrang hospital, the number of dissatisfied respondents amounted to 1 person $(1 \%)$, a respondent who is quite satisfied as much as 12 people $(12 \%)$. The respondent who was satisfied amounted to 53 people $(53.0 \%)$ while being very satisfied amounting to 34 people (34\%). Meanwhile, at Dr Sumantri Parepare hospital, the number of unsatisfied respondents amounted to 1 person $(1 \%)$, the respondent who is quite satisfied as much as 12 people (12\%). The respondent who was satisfied amounted to 46 people $(46.0 \%)$ while being very satisfied amounting to 41 people $(41.0 \%)$ (Table 1$)$

Table 1 Respondents Distribution Based on Patient Satisfaction Rate 


\begin{tabular}{|c|c|c|c|}
\hline \multirow{2}{*}{ Hospital } & \multirow{2}{*}{ Patients Satisfaction } & \multicolumn{2}{|c|}{ Amount } \\
\hline & & $\mathbf{n}$ & $\%$ \\
\hline \multirow{3}{*}{ Andi Makkasau } & Quite satisfied & 13 & 13.0 \\
\hline & Satisfied & 48 & 48.0 \\
\hline & Very satisfied & 39 & 39.0 \\
\hline \multirow{4}{*}{ Lasinrang } & Unsatisfied & 1 & 1.0 \\
\hline & Quite satisfied & 12 & 12.0 \\
\hline & Satisfied & 53 & 53.0 \\
\hline & Very satisfied & 34 & 34.0 \\
\hline \multirow{5}{*}{ Dr. Sumantri } & Unsatisfied & 1 & 1.0 \\
\hline & Quite satisfied & 12 & 12.0 \\
\hline & Satisfied & 46 & 46.0 \\
\hline & Very satisfied & 41 & 41.0 \\
\hline & Total & 100 & 100 \\
\hline
\end{tabular}

Based on the category of customer value, the result that in the Andi Makkasau hospital The number of respondents in the category is quite good that is as much as 4 people (4.0\%). Respondents who were in a good category amounted to 67 people $(67.0 \%)$, while an excellent number of 29 people (29.0\%). In the Lasinrang hospital the number of respondents who were in the category of not good 1 person $(1.0 \%)$, good enough to be as many as 7 people (7.0\%). Respondents who were in a good category amounted to 56 people $(56.0 \%)$, while an excellent number of 36 people (36.0\%). While at Dr Sumantri hospital. The number of respondents who are in the category of not good amounted to 1 person (1.0\%), good enough that is as much as 7 people (7.0\%). Respondents who were in a good category amounted to 54 people $(54.0 \%)$, while an excellent number of 38 people (38.0\%). (Table 2)

Table 2 Respondents distribution based on Customer Value

\begin{tabular}{|l|l|l|l|}
\hline \multirow{2}{*}{ Hospital } & \multirow{2}{*}{ Customer Value } & Amount & \\
\cline { 3 - 4 } & & $\mathbf{n}$ & 4.0 \\
\hline \multirow{3}{*}{ Andi Makkasau } & Good enough & 4 & 67.0 \\
\cline { 2 - 4 } & Good & 67 & 29.0 \\
\cline { 2 - 4 } & Excellent & 29 & \\
\hline
\end{tabular}


Cont... Table 2 Respondents distribution based on Customer Value

\begin{tabular}{|l|l|l|l|}
\hline \multirow{4}{*}{ Lasinrang } & Not good & 1 & 1.0 \\
\cline { 2 - 5 } & Good enough & 7 & 7.0 \\
\cline { 2 - 5 } & Good & 56 & 56.0 \\
\cline { 2 - 5 } Dr. Sumantri & Excellent & 36 & 36.0 \\
\hline & Not good & 1 & 1.0 \\
\hline & Good enough & 7 & 7.0 \\
\cline { 2 - 5 } & Good & 54 & 54.0 \\
\hline & Excellent & 38 & 38.0 \\
\hline & Total & 100 & 100 \\
\hline
\end{tabular}

In the category, IUR cost obtained the result that in the Andi Makkasau hospital number of respondents who are in the category of not good 1 person $(1.0 \%)$, good enough that is as much as 31 people $(31.0 \%)$. Respondents who were in a good category amounted to 46 people $(46.0 \%)$, while an excellent number of 22 people $(22.0 \%)$. In the Lasinrang hospital the number of respondents who were in the category of Not good 3 persons (3.0\%), good enough that is as much as 20 people
(20.0\%). Respondents who were in a good category amounted to 49 people (49.0\%), while those in a very good category amounted to 28 people $(28.0 \%)$. While at Dr Sumantri hospital the number of respondents who are in the category is not good 3 people (3.0\%), good enough that is as much as 16 people $(16.0 \%)$. Respondents who were in good category amounted to 52 people $(52.0 \%)$, while a very good number of 29 people (29.0\%) (Table 3).

Tabel 3 Respondents distribution based on Iur Cost

\begin{tabular}{|l|l|l|l|}
\hline \multirow{4}{*}{ Hospital } & \multirow{2}{*}{ Iur Cost } & Amount & \% \\
\cline { 2 - 4 } & & $\mathbf{n}$ & 1.0 \\
\hline \multirow{5}{*}{ Andi Makkasau } & Not good & 1 & 31.0 \\
\cline { 2 - 4 } & Good enough & 31 & 46.0 \\
\cline { 2 - 4 } & Good & 46 & 22.0 \\
\cline { 2 - 4 } & Excellent & 22 & 3.0 \\
\hline \multirow{5}{*}{ Lasinrang } & Not good & 3 & 20.0 \\
\cline { 2 - 4 } & Good enough & 20 & 49.0 \\
\cline { 2 - 4 } & Good & 49 & 28.0 \\
\cline { 2 - 4 } & Excellent & 28 & 3.0 \\
\hline \multirow{5}{*}{ Dr. Sumantri } & Not good & 3 & 16.0 \\
\cline { 2 - 4 } & Good enough & 16 & 52.0 \\
\cline { 2 - 4 } & Good & 52 & 29.0 \\
\hline & Excellent & 100 & 100 \\
\hline
\end{tabular}


Analysis of the results using the line analysis with the application AMOS then obtained 0.510 .87 the results that IUR cost (convenience of service, Security Service and service assurance) directly affect patient satisfaction (suitability expectations, interest revisit, and willingness to inform) with a coefficient of beta 0.43 and affect indirectly through Customer Value (services, quality, cost, social, information and experience) with a The relationship between variables obtained results that the IUR variable cost in conjunction with the Customer Value variable $p=0.001$ (significant). The Customer Value variable in conjunction with the patient satisfaction variables generated value $\mathrm{P}=$ 0.001 (significant) and IUR variable cost in conjunction with the patient satisfaction also generated value $\mathrm{P}=0.001$ (significant). As for the relationship between variables can be seen in the image below:

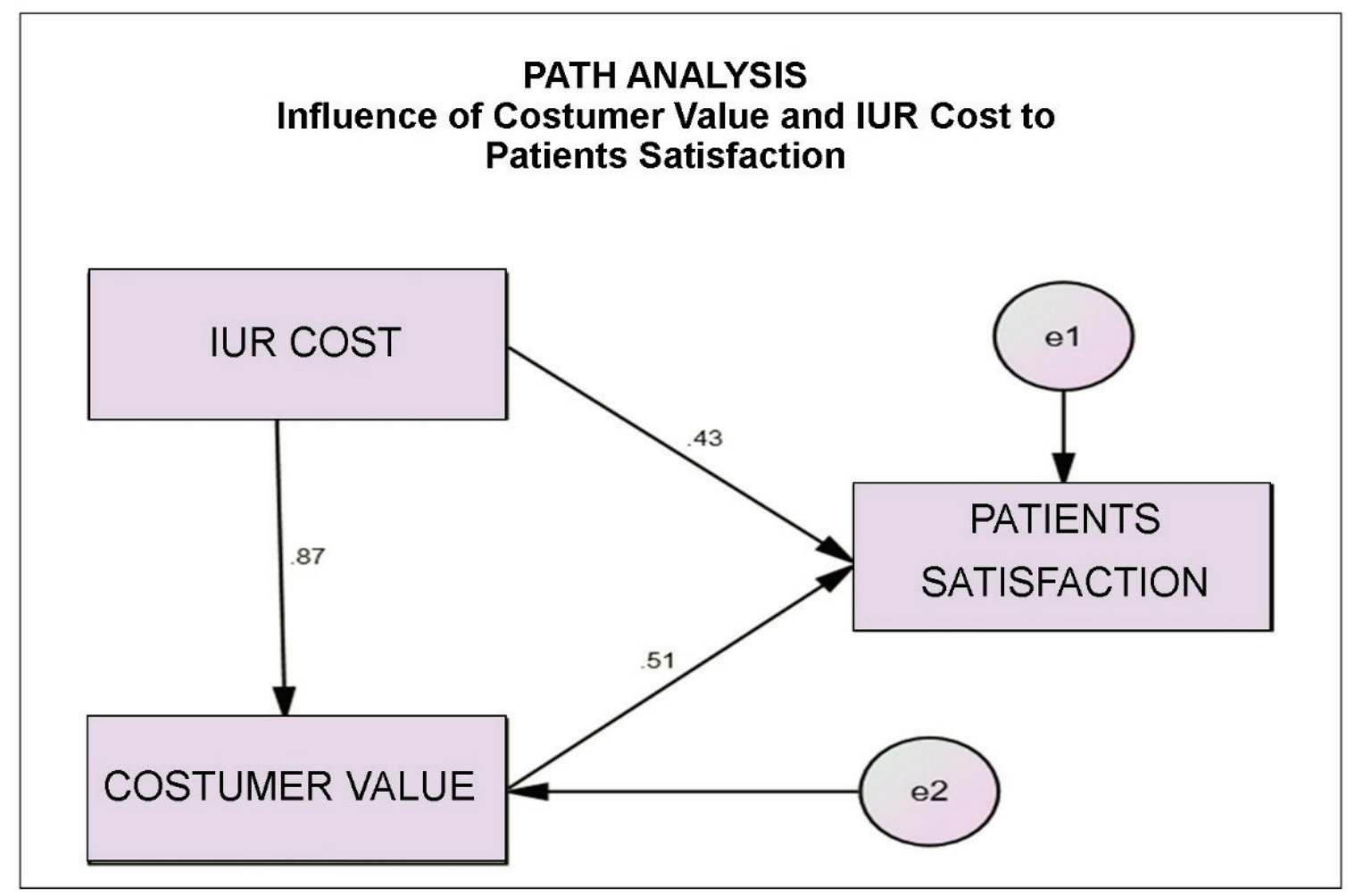

Figure 1. Customer Value and Iur cost analysis influence on patient satisfaction

\section{Discussion}

IUR cost is an additional fee paid by the participants of BPJS at the time of obtaining a higher health service benefit of its rights. The rights owned herein are the rights of patients based on their participation. The analysis of the pathway using AMOS shows that in addition to directly affect the IUR costs also influence indirectly to patient satisfaction through Customer Value (services, quality, cost, social, information, experience) with beta coefficient 0.87 and 0.51 .
Based on the coefficient, it can be calculated that the indirect effect of the IUR cost is $0.87 \times 0.51=0.44$. It can be interpreted that the indirect influence of IUR costs to the patient's satisfaction of $44 \%$. Based on these results it can be seen that the indirect influence of IUR costs greater than the direct influence of $43 \%$. This positive figure indicates that IUR costs significantly and positively affect patient satisfaction. So the better assessment of IUR cost will boost the increase in customer value or customer value. Better Customer Value will drive the increasing level of patient satisfaction. 
Allahham also states that some marketing-related literature states that there is a positive relationship between satisfaction to the cost of the value perceived by the customer. Hospitals that provide customers with a higher value are likely to be able to satisfy them, it can improve patient loyalty. This is in line with the results of the model on research where the influence of iur cost to satisfaction through customer value. So that it can be interpreted that the IUR costs obtained by the patient can affect the customer value or the judgment of the services obtained. The patient's assessment of the service affects the level of contentment he felt. ${ }^{9}$

Satisfaction as a comparison between expectations or expectations of the patient will quality with the quality of service obtained. So the patient's expectation or expectation and quality of service are perceived as a major factor affecting patient satisfaction. But in addition to these two factors, the cost factor incurred today has also been regarded as a major factor in patient satisfaction. ${ }^{10}$ in general, patient loyalty and return interest are influenced by the level of satisfaction of the service they received earlier. Therefore, it is very important to understand the factors that affect patient satisfaction based on the service paradigm.

Indonesian Ministry of Health states that the hospital tariff is a reward received by the hospital for services from services and non-service activities provided to the service users. Service users, in this case, our patients. So it can be interpreted that the hospital tariff is a reward received by the hospital for the service provided to the patient. ${ }^{11}$ hospitals also need to think about the tariff of its services so that the tariff is appropriate or appropriate in the eyes of consumers. Tariffs that are inappropriate or too expensive will instead make the consumer dissatisfied, complained and eventually moved to another health service. ${ }^{12}$ Tariff is part or all of the cost of organizing activities of medical and non-medical services that are charged to the public in exchange for services received.

Tjiptono states that the value can be defined as the ratio between perceived benefits to the price. If the perceived value of the customer is high, it will create maximum satisfaction. This is in line with the research results where the cost is a factor that affects the customer value or customer's assessment of the service provided by the hospital. The value of this patient then affects the feeling of contentment in the patient. ${ }^{13-15}$ Customer value) has become an ongoing concern in building and supporting the benefits of competition and creating customer relationship management. The value of a customer related to the use of a or more is something customers feel. Customer value is a strategic weapon in attracting and holding customers. Customer value has become one of the most important factors in the success of a service provider including hospitals.

\section{Conclusions and Suggestions}

The research concluded that IUR costs directly affect patient satisfaction with the beta coefficient of 0.43 and indirectly affect the Customer Value with the beta coefficient 0.87 and 0.51 . The IUR variable cost significantly affects customer value. Customer value variables relate significantly to patient satisfaction and the IUR variable costs significantly affect patient satisfaction. The advice that can be given is that the hospital needs to improve the quality of its ministry in order to increase patient satisfaction to the services provided.

Ethical Clearance- Taken from University ethical committee

\section{Source of Funding- Self \\ Conflict of Interest- Nil}

\section{References}

1. Riswardani, Y.T.S. influence facilities, cost and promotion to the satisfaction of inpatient patients. PHARMACY Journal of Economic Resource Management. 2013; 4 (2): 88-98.

2. Alimudin, A. Dhaniarti, I. Sukoco, A. Model of Customer Value Approach for Improving Satisfaction of The Hospital Patients. Journal of SINERGI. 2017; 7 (2): 30-40.

3. BPJS Health. https://bpjs-kesehatan.go.id/bpjs/ index.php/jumlahPeserta. 2019. (accessed 26 April 2020).

4. Aryani, F, Husnawati, Muharni, S, Liasari, M and Richa Afrianti. Outpatients ' Satisfaction Analysis of Pharmaceutical Service Quality in Pharmacy Installation of Ibnu Sina Islamic Hospital Pekanbaru. Journal PHARMACY. 2015; 12 (01): 
101-112.

5. The Republic of Indonesia. State No. 44 the year 2009 on Hospitals. Jakarta: President of Indonesia. 2009.

6. Basri, A. H. and Leoganda, D. F. Relationship Of Inpatient Room With BPJS Patient Satisfaction Rate. Journals of Ners Community. 2016; 07 (01): 47-54.

7. Tjiptono, F. Principles of Total Quality Services. Yogyakarta: Andi Offset. 2005.

8. Rizal, A dan Yeni, R. Health Service Quality Relationship with Patient Satisfaction Level at BP. Kelayan Dental Clinic in Banjarmasin City. An NADAA Journal of Public Health Faculty of Public Health UNISKA. 2014; 1(1): 26-31.

9. Allaham, A. Determinants of Customer Satisfaction in Healthcare Services. International Journal of Business and Management Invention (IJBMI). 2013; 2 (3): 59-63.

10. Alimudin, Arasy, et al. Model of Customer Value Approach for Improving Satisfaction of the
Hospital Patients. SINERGI 2017:30-40

11. Ministry of Health. Regulation of the Minister of Health No. 852015 on National Hospital tariff patterns. Jakarta: Indonesia Ministry of Health, 2015.

12. Sismiyati, A. Analysis of quality of service, tariff and facilities to patient satisfaction (study in inpatient RSKIA Ummi Khasanah Bantul. Prodi management UPY. 2017.

13. Tjiptono, F. Marketing strategy. Yogyakarta: Andi Offset. 2015.

14. Luwu ABT, et al. Air germ numbers in Bougenville's care room at H. Andi Sulthan Daeng Radja Bulukumba Hospital. Enferm Clin. 2020. https://doi.org/10.1016/j.enfcli.2019.10.113

15. Fauzan, et al. Factors related to quality of life of elderly victims of natural disasters in Palu City. Enferm Clin. 2020. https://doi.org/10.1016/j. enfcli.2019.10.064 